\title{
Potential and challenges of the Serengeti-Ngorongoro Biosphere Reserve, Tanzania
}

\author{
Nina Botha, Hubert Job \& Fidelcastor Kimario
}

Keywords: biosphere reserve, human-wildlife conflicts, park-people relations, Serengeti-Ngorongoro, Sub-Saharan Africa

\section{Abstract}

This article examines whether the Serengeti-Ngorongoro Biosphere Reserve, Tanzania, is successfully mitigating the immense challenges that rising population density and growing land-use pressure, as well as climate change and tourism, pose to vulnerable biodiversity hotspots, such as ancient Afromontane forests. The biosphere reserve's management approach to ecological and socio-cultural heritage was analysed using the Global-Local Drivers of Change model as a theoretical basis, together with The Economics of Ecosystems and Biodiversity (TEEB) analysis framework. This empirical study of a relatively old Sub-Saharan African biosphere reserve (established in 1981) used a qualitative research approach, where data was collected from focus groups living in the reserve, and semi-structured interviews with Ngorongoro Conservation Area officials and other main stakeholders. Results show that the management focus on environmental conservation over socio-cultural heritage has led to population growth, cultural change and landscape transformation, leading to human-wildlife conflicts and negative park-people relationships. It is concluded that this biosphere reserve needs to better exploit its vast potential and adjust its institutional structure and operational strategies to align with modern Other Effective Area-Based Conservation Methods.
Profile

Protected area

Serengeti-Ngorongoro

Biosphere Reserve

Country

Tanzania

\section{Introduction}

Africa has two biosphere reserve (BR) networks: ArabMAB with 33 BRs in 12 states, and AfriMAB with 85 BRs in 31 Sub-Saharan countries (UNESCO 2020). Fourteen African countries do not currently have any BRs. BRs can generally be divided into those established before 1995, and those founded after 1995 (the year of the Seville strategy) when UNESCO BR priorities changed to a mandated three-zone approach. In the AfriMAB network, there are 38 mountainous BRs, 17 of which include Afromontane forests. These forests occur above $1500 \mathrm{~m}$ and are rich in endemic biodiversity as they pre-date the formation of the African Rift Valley and the aridification of East Africa (Grimshaw 2001), making them global biodiversity hotspots (Newmark 2002). Geographically they occur from the Ethiopian Highlands in the north, down along the mountains bordering the East African Rift, to South Africa (Figure 1).

These forests contain a rich biodiversity and provide vital ecosystem services, such as watershed protection, substantial carbon sinks, cultural sites and international tourist attractions. However, the forests are threatened by the high population growth of resource-dependent communities (Abiem et al. 2020) who exploit them for agriculture and pasture (Price et al. 2011). The promotion of sustainable development and environmental conservation is therefore crucial (Botha 2020). The three-zone post-Seville BR approach is seen as an ideal solution (Job et al. 2019), where each zone (core, buffer and transition) has a specific role in landscape-scale conservation. The buffer and transition zones are driven by local grassroots development based on the UN's sustainable development goals for 2030 (Carius \& Job 2019). BRs that are actively following this approach are in line with the contemporary global conservation concept of Other Effective Area-Based Conservation Methods (OECMs) (IUCN-WCPA 2019).

This study aims to determine whether the Serengeti-Ngorongoro Biosphere Reserve (SNBR) is mitigating the challenges that the Afromontane forests face, by examining its conservation efforts, and its management of the local ecological and socio-cultural heritage. The findings for SNBR will be compared to two other Afromontane forest BRs, namely Kruger to Canyons (K2C) and Kafa, as they share key characteristics such as high population growth and consequent forest exploitation, as well as high tourism potential. Like SNBR, the K2C BR (South Africa) has a highly popular tourism destination (Kruger National Park) as its core, while the inhabitants of Kafa BR (Ethiopia) live in more traditional communities that, like the Maasai communities in SNBR, are heavily reliant on natural resources for their livelihood.

The first objective of this paper is to analyse parkpeople relations in SNBR to determine the protected areas' (PAs) potentials and challenges. The second objective is to compare these dynamics to the situations in the above-mentioned Afromontane forest BRs, to determine the potential efficacy of SNBR governance strategies in mitigating these challenges. 


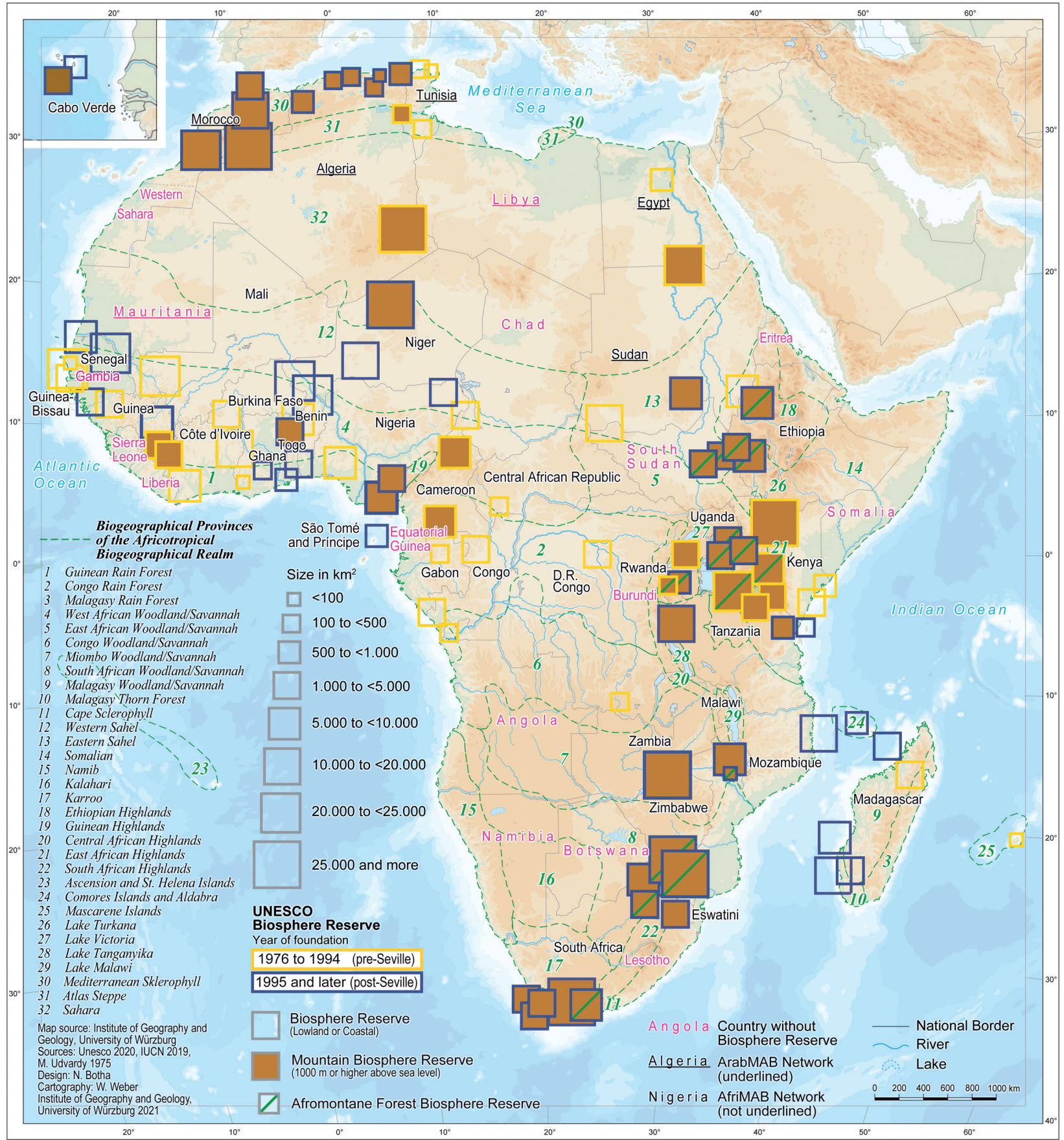

Figure 1 - African BR classifications and location of mountain BRs with Afromontane Forests.

\section{Theoretical approach}

The Global-Local Drivers of Change model (Becken \& Job 2014) is used in this study, in conjunction with TEEB analysis framework. The change model identifies influences and challenges in SNBR and argues on two spatial levels (Figure 2). The first level has four external global-scale drivers of change (population development, land-use, climate change and energy use). On the second level, these drivers interact with four local-scale dimensions (conservation, community, tourism, and meaning of landscape), which both influence and are influenced by the PA.
These eight aspects of the Global-Local Drivers of Change framework were investigated from the perspective of the Ngorongoro Conservation Area (NCA) community and management authority; they were also observed directly by the researchers.

The current state of each aspect, the changes each has undergone, and the contributions each makes to the NCA system were explored using TEEB analysis framework. TEEB has four components, each of which was investigated in relation to each aspect of the Global-Local Drivers of Change framework. These four aspects are: impacts, which are the contributions of the ecosystem to human wellbeing; outcomes, or changes 


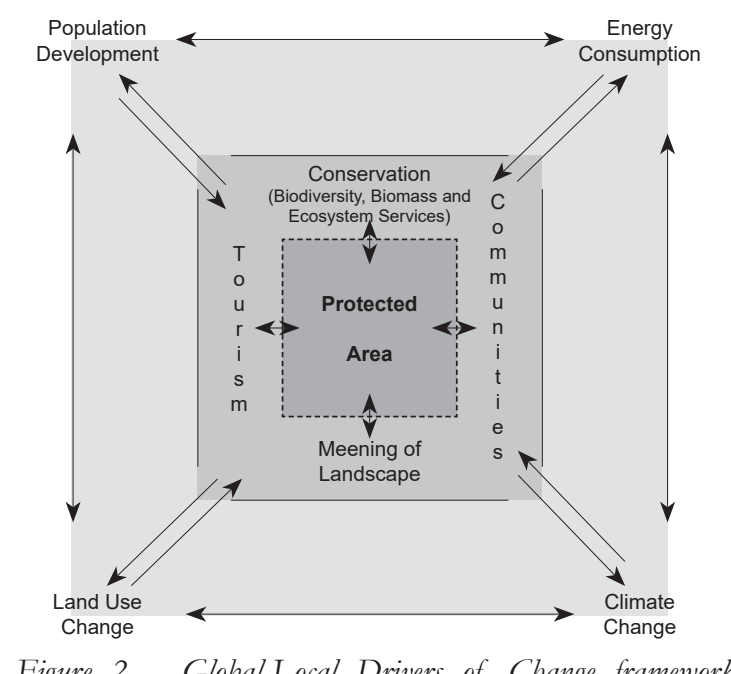

Figure 2 - Global-Local Drivers of Change framework (Source: Becken \& Job 2014).

in all capital bases, which include cultural capital such as traditions, religion, knowledge and social institutions that influence the local community; flows, which are defined as visible and invisible value chains; and stocks, which are the capital base for production (TEEB 2021). Together, these two frameworks were used to create research materials and enable the analysis and discussion of the data obtained. The approach enabled questions relating to SNBR's management approach to ecological and socio-cultural heritage to be answered.

\section{Methodology}

This empirical study follows a qualitative research approach that focuses on SNBR as a case study. Data was collected from resident Maasai and park staff in NCA, using a set of open questions, during a six-week field study in summer 2018. The observation research technique was used to collect supplementary evidence for the biological, economic and social infrastructure conditions in NCA that determine park-people relations. Additionally, official documents were analysed.

A total of 104 participants from eight wards were involved in focus group discussions. (The ward is the lowest-level government administrative structure within the conservation area.) Participants were randomly selected concerning age and gender. Open questions were used to guide the discussions. A focus group was held in each ward. The groups ideally comprised men, women and young people, but in Misigyo, Ngorongoro, Endulen and Nainokanoka, full participation of local women and young people was not possible, due to cultural barriers (Figure 3). For instance, Maasai woman cannot participate in meetings where men are present; even if they attend, they will not contribute. In meetings where older men (especially leaders) were present, young men seldom contributed to discussions.

The Tanzanian Village Land Act of 1999 governs land management and administration in villages and hamlets in rural areas outside NCA. NCA is a legally declared PA; the mandate of the land is bestowed on the NCA Authority.

The following procedures were carried out in order to conform to ethical research requirements:

- participants were assured of their anonymity and the confidentiality of the information they would provide;

- informed consent was obtained from respondents, especially for the methods that were used to collect data, such as recording;

- permits and letters of introduction from NCA and village offices were obtained;

- appointments were planned and booked in advance; participants registered with village offices and NCA upon arrival.

Seven semi-structured expert interviews were conducted with: a Pastoral Council member, the chief conservator, and NCA staff members who were responsible for resource protection (3 individuals), tourism, ecology, community, and cultural heritage. All interviews were recorded, but due to challenges relating to the area's remoteness, some recordings needed to be supplemented with written notes. The data were transcribed, coded and grouped for interpretation. A deductive coding style with pre-determined themes and categories was employed, which guided the analysis. The themes were organized in MS Excel according to the eight categories of the Global-Local Drivers of Change framework. The findings were then analysed and compared to those from similar Afromontane forest BRs, to determine whether SNBR is successfully mitigating the challenges, and whether there is potential to improve mitigation further in order to better attain the goals of OECM.

\section{Case study}

NCA is a multi-designated PA; it is internationally recognized as a World Heritage site (1979/2010), a UNESCO BR (1981), and a Global Geopark (2018) (but each with different perimeters), thanks to its diverse and unique natural features. Because of these features, it is a popular tourist destination, with a tourism income of US\$ 63 million in 2019, which was $11 \%$ higher than in 2018 (NCAA 2020). Its most famous attraction is the Ngorongoro Crater $\left(264 \mathrm{~km}^{2}\right)$, which is the main source of income of the NCA district administration. SNBR was chosen for a case study because the BR's historical context creates environmental and socio-economic problems (Larsen et al. 2020). SNBR is one of Tanzania's five BRs (which together cover $92568 \mathrm{~km}^{2}$, roughly $10 \%$ of the country). The national MAB committee would like to add five more BRs (Bell et al. 2013). The SNBR itself covers $23051 \mathrm{~km}^{2}$, and the volcanic massifs, which include the Ngorongoro Crater, reach an altitude of $3587 \mathrm{~m}$ (UNESCO 2019a). The core zone of the SNBR, the 


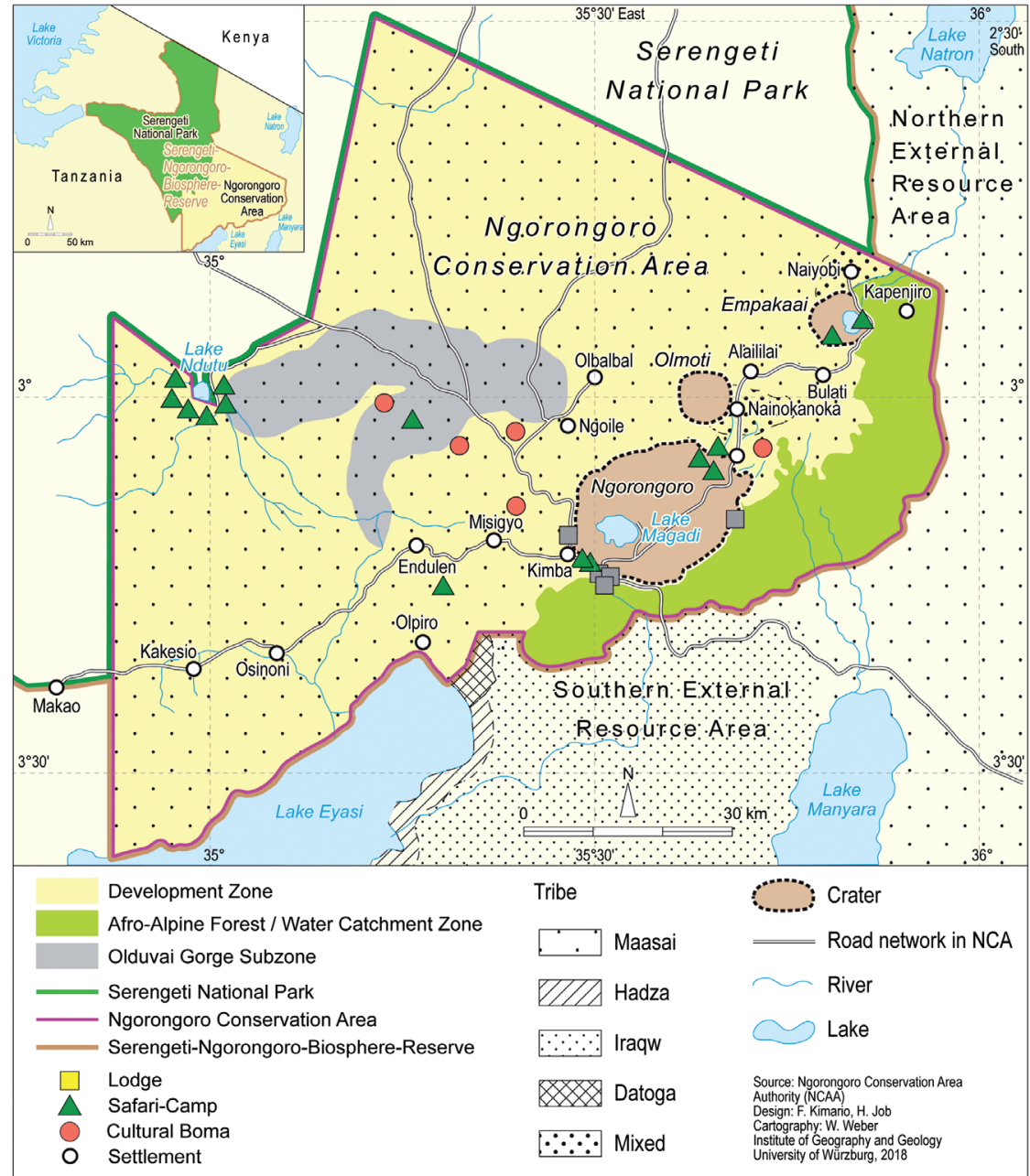

Figure 3 - Serengeti-Ngorongoro Biosphere Reserve including Ngorongoro Conservation Area and Serengeti National Park (Kimario et al. 2020).

Serengeti National Park (NP), was founded in 1951 by the British colonial administration. The Ngorongoro Conservation Area was part of this NP until 1958, when the two PAs were separated (Figure 3), and the Maasai were relocated from their indigenous semi-arid grazing land in the Serengeti NP to the Ngorongoro Conservation Area (Job \& Schmid 2011).

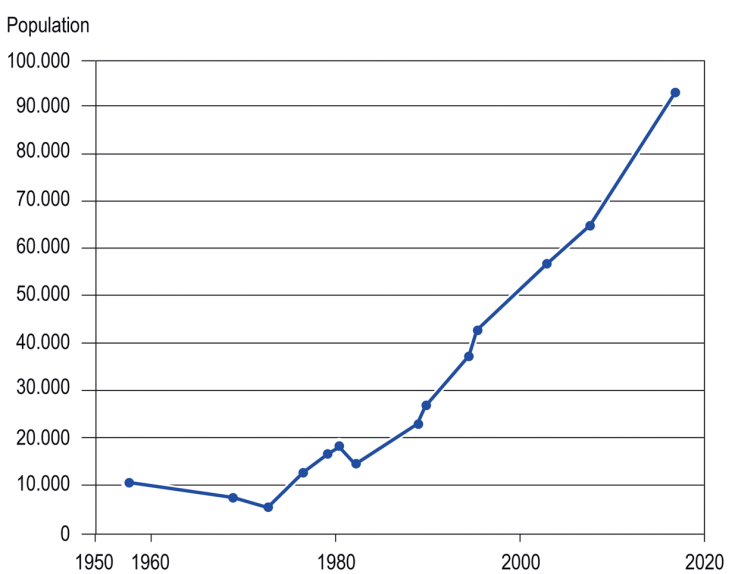

Figure 4 - Population trend of Ngorongoro Conservation Area (1954-2017) (URT 2017).
The newly formed NCA intended to allow a maximum of 20000 herders to continue their traditional pastoral lifestyle on the fertile soil, formed of young volcanic ash. This healthier environment together with the cultural practice of polygamy resulted in a $4 \%$ annual population growth (Figure 4). The latest census (URT 2017) indicated that $50 \%$ of the population was under 14 years of age, and that only $36 \%$ of people over the age of 5 was literate. (Pre-primary education focusing on numeracy and literacy starts at the age of 4 (Mbise 1996)). Livestock is a key component of Maasai culture (Merker 1904), and while livestock numbers have increased, the livestock-human ratio has fallen (from 2.4 livestock units per inhabitant in 1994, to 2.0 units today). This ratio decrease can be attributed to epidemics and droughts that reduced the quality of the grazing (Kimario \& Job 2021).

\section{Results}

The results of the focus group discussions, semistructured expert interviews, and observations on SNBR's management approach to ecological and socio-cultural heritage are organized and discussed in 


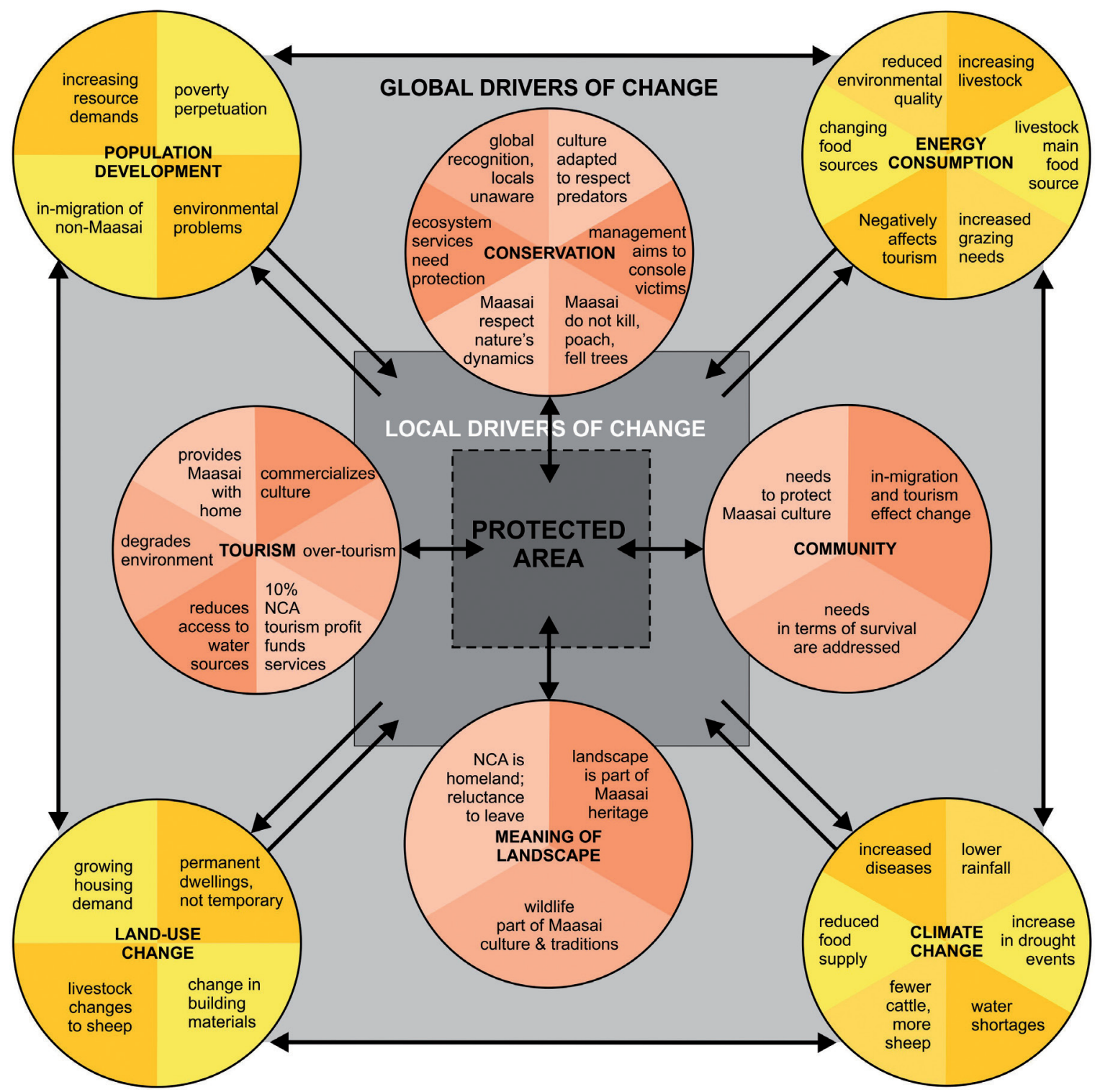

Figure 5 - Summary of NCA's role in the Global-Local Drivers of Change framework. Source: own design after Becken \& Job 2014.

terms of the categories of the Global-Local Drivers of Change (Figure 5).

\section{Global drivers of change}

\section{Population development}

The steep population growth rate of both the Maasai and their livestock since their relocation is straining resources within the boundaries of NCA. Increasing demands for land, natural resources, social services and infrastructure compete directly with the ecosystem and its biodiversity; for example, over-population of people and livestock around water sources has given rise to as yet unidentified water-borne diseases in people, which also infect wildlife. The communities living in NCA largely depend on NCA to provide schools, health centres, roads, water, and livestock extension services (e.g. veterinary and nutritional services, training in animal husbandry, knowledge- sharing), which NCA's management is not always able to supply. This deficit contributes to poverty through, for example, the low literacy rate caused by a lack of educational services.

These resource constraints are amplified by the in-migration of non-Maasai cultures attracted by the perceived social and environmental opportunities in NCA. The migrants, mostly Arushas and Merus, have a detrimental effect on the traditionally sustainable culture of the Maasai. For example, the semi-nomadic Maasai who survived on the meat, milk and blood of their cattle and goats now, influenced by the migrants, also keep sheep and practise small-scale agriculture. This is against the rules of NCA, as both these practices inevitably degrade the landscape, which in turn affects not only the Maasai's traditional grazing lands, but also tourism within NCA. As a solution, the management proposed a project that encourages community members who no longer wish to pursue the tra- 
ditional Maasai way of life to live outside NCA. The idea was to buy land and build infrastructure outside NCA, at no cost to the community, but this proposal was rejected by most community members.

\section{Energy consumption}

Within the traditional context of SNBR, energy consumption refers to the flow and use of consumable natural resources. The natural environment of NCA provides its inhabitants with firewood, food and grazing for their cattle and goats, thus supporting the Maasai's traditional livestock rearing, which is their main socio-economic activity. Livestock is an important source of food and material for the Maasai, as well as a symbol of wealth and a source of pride. It is therefore understandable that as the Maasai population expanded, so did the livestock population, which has become problematic. The grazing rate has become unsustainable and is now having a negative effect on ecological systems and tourism. This led to a ban on livestock entering the Ngorongoro Crater, which is one of a few permanent sources of water.

Be it through climate change or cultural influences and increased demand for food, the diet of NCA's communities has changed. For example, foods prohibited within Maasai culture, including fish and chicken, are now commonly consumed. This cultural shift affects the natural resources needed by the community; some communities now grow potatoes, beans and maize, which requires agricultural land and permanent settlement. This is illegal within NCA, which aims to conserve the natural landscape as well as Maasai culture.

\section{Land-use change}

The growing population, their increased food demand and their changing cultural practices all contribute to landscape change. This larger population moves into once uninhabited areas to build houses. Furthermore, when the Maasai leave their semi-nomadic lifestyle, they need more permanent structures when they settle. Small, once separate villages around NCA are now merging. Traditional materials like grass, soil and dung are being replaced with bricks, cement and iron sheets. This negatively affects the natural landscape and contradicts the principles of NCA. The cultural shift is seen also in the types of livestock being raised and their impact on the environment: the focus group discussions revealed that sheep have become an important type of livestock, but their introduction has led to overgrazing, invasive and unpalatable vegetation, and soil erosion.

\section{Climate change}

Changes to NCA's climate include lower rainfall and increased drought events; water shortages threaten the communities' food supply to such an extent that subsidized cereals need to be provided twice a year. In reaction to the drought, communities keep fewer cattle and goats as they have high water and grazing requirements. Sheep are now preferred because they are more drought tolerant.

An increase in drought-related diseases affects humans and livestock alike. NCA lost around 7400 head of cattle from unknown diseases during 2017. As one focus group participant recalled: "It was during the dry season, but some cows even died at the water ponds. So, we cannot say they died because of drought."

\section{Local drivers of change}

\section{Community}

Although NCA supports communities living within it, it is also partly responsible for cultural changes caused by the relocation of the Maasai in 1959. The in-migration of other cultures into SNBR and increasing contact with tourists and their cultures are changing traditional Maasai culture. This is evident in the types of clothing that the Maasai wear, the use of mobile phones, and the changing behaviour of young people, who now tend to gather around shopping centres, play cards or pool, and consume alcohol. The community asked NCA's management to address these issues by promoting and protecting the cultural practices of the Maasai through education and awareness-raising.

NCA's purpose has always been to improve environmental conservation and tourism. Social issues have not received the same level of attention, causing tension between NCA's management and local communities. The community feels that they support the NCA concept, but that the management neglects them: "There is no rural environmental appraisal involving the local community, yet the indigenous culture promotes the existence of Ngorongoro Conservation Area" was one statement we heard.

NCA's management does, however, have several departments that care for the community and their wellbeing. The Community Development Department addresses issues relating to food security, veterinary services, infrastructure and livestock. This is a much-needed service in light of the increased incidences of the transmission of diseases between livestock and wildlife. A prominent recent concern has been water shortages: the permanent water sources in NCA are within fragile ecosystems, and community access is therefore restricted. Dams and ponds were consequently constructed for water collection during the wet season.

\section{Tourism}

Tourism within NCA is a double-edged sword. On the one hand, it provides the Maasai with extra income through small-scale businesses, tourism activities, and employment at lodges. Tourism further benefits the community, as $10 \%$ of NCA's annual tourism income is used to fund community services, such as healthcare. On the other hand, tourism has had detrimen- 


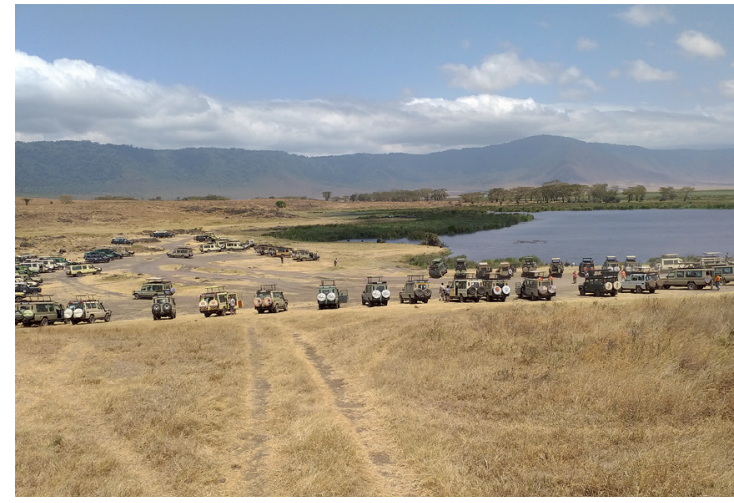

Figure 6-Over-tourism in the Ngorongoro Crater (Kimario 2018).

tal effects on the environment and the culture of the Maasai. The Ngorongoro Crater is biophysically sensitive, and if the number of tourists and associated tourist activities exceed the acceptable limits, its natural beauty and biodiversity are threatened. Communities are wary of increasing tourism development, as waste disposal, access roads, water infrastructure and loss of land to lodges degrade the environmental quality of the PA (Figure 6). Culturally, tourism commercializes traditional Maasai practices: they entertain tourists at cultural bomas by singing and dancing for a fee, and by selling traditional beadwork, ornaments and carvings as souvenirs. These activities are staged and lack the authenticity of true Maasai cultural practices.

\section{Meanings of the landscape}

The landscape of NCA has different meanings for different stakeholders: for NCA's management, it is a source of tourism revenue; for tourists, it is the backdrop of their wildlife experience; but for the Maasai, it is part of their heritage. For them, the landscape is a source of materials, food and medicine, and contributes to their traditions. For example, honey collected from the forest is used in Engotooroki, a ceremonial brew. The Maasai accept the landscape and the wildlife it contains as part of their culture. The killing and consumption of wild meat are prohibited, and gazelles and buffaloes are allowed to graze next to cattle. As one participant stated: "They feed together, and if a cow gets lost, you can find it in a group of zebras." The livestock also experience attacks by predators, but the Maasai also accept this: "No Ngorongoro without lions, even if they are predators."

Communities are modernizing, and during one focus group discussion it was suggested that if the park management wanted to relocate people to areas outside NCA, it is educated young people who should be moved. Some elders believe differently: "If we are to move, then we should return to Serengeti and nowhere else." The Maasai see themselves as an integral part of the landscape of NCA, and their sustainable culture has contributed to its international recognition as a World Heritage Site and UNESCO BR.
The Maasai focus group discussions revealed which aspects of daily life within NCA they perceived as positive, negative or neutral. The aspects they regarded as the most positive include tourism, traditions, culture and custodianship. The aspects that they perceived to be the most negative were livestock problems, access to water, benefit-sharing issues, problems of co-existence and strained relationships. Aspects that did not arouse any strong opinions were people, population, livelihood and the killing of animals.

\section{Conservation}

The Maasai, their culture, and especially their connection to the natural dynamics in the landscape are fundamental to NCA's success. As one respondent stated: "In areas from where indigenous people were removed, there is no wildlife like [there is in] NCA." Wild grazing animals are often found around the Maasai's pastoral homesteads alongside their livestock, because here the wild animals are protected from predators and have access to water. As confirmed by the focus groups, the Maasai are environmental custodians: they do not kill or poach wildlife, or cut down trees. (They are, however, allowed to use cut and fallen branches for their needs.) When they encounter outsiders illegally entering the area, they report them to the authorities.

Wildlife, however, does also pose a danger to this community, especially buffaloes and lions, which frequently injure or kill humans and livestock. Other noteworthy predators are leopards and hyenas. Local communities have learned to adapt to these threats, through the clothes they wear, weapons they carry, and knowledge of what should be done when they encounter certain wild animals. To support the communities, the reserve has a Protection Department that aims to reduce human-wildlife conflict and console its victims.

The Maasai have created a sustainable lifestyle, with productive lands that still contain biodiversity. It is therefore concerning that the culture of the communities living within NCA is changing. NCA's natural assets led to its international recognition as a UNESCO BR (1981), World Heritage Site (1979, extension 2010), and Global Geopark (2018), but when these designations were mentioned during focus group discussions, the community did not know of them. While these organizations praise NCA's conservation efforts, more work is needed, especially on the protection of ecosystem services that keep NCA healthy, such as its natural water-storage capacity.

\section{Discussion}

NCA tries to manage environmental concerns and the local communities' basic needs separately. To be in line with the OECM approach, these must be managed together with cultural factors as one holistic, integrated system (IUCN-WCPA 2019). This can be a challenge, especially where resources are scarce, but it is vital for the long-term sustainability of SNBR. More 
Table 1 - Overview of Global-Local Drivers of Change in Serengeti-Ngorongoro Biosphere Reserve (SNBR), Kruger to Canyons Biosphere Reserve (K2C BR) and Kafa Biosphere Reserve (BR) (own compilation).

\begin{tabular}{|c|c|c|c|}
\hline Global-Local Drivers of Change & SNBR & K2C BR & Kafa BR \\
\hline \multicolumn{4}{|l|}{ The global drivers of change } \\
\hline Population development & $\begin{array}{l}\text { About } 92,000 \text { people live within } \\
\text { the biosphere reserve's (BR's) } \\
92568 \mathrm{~km}^{2} ; 50 \% \text { of the popula- } \\
\text { tion are under } 14 \text { years of age, } \\
\text { and most live in poverty. }\end{array}$ & $\begin{array}{l}\text { About } 1.5 \text { million people live } \\
\text { within the BR's } 26080 \mathrm{~km}^{2} ; \\
32 \% \text { are under the age of } 15 ; \\
\text { the unemployment rate is } 41 \% \\
\text { (between ages } 15 \text { and } 64 \text { ). }\end{array}$ & $\begin{array}{l}\text { About } 608000 \text { people live in an } \\
\text { area of } 5406 \mathrm{~km}^{2} .44 \% \text { of this } \\
\text { population are aged under } 14 .\end{array}$ \\
\hline Energy consumption & Firewood, food, grazing & $\begin{array}{l}\text { Firewood, food, grazing, } 97 \% \\
\text { supplied with electricity }\end{array}$ & $\begin{array}{l}\text { Food, grazing, traditional } \\
\text { agriculture }\end{array}$ \\
\hline Land-use change & Settlements, agriculture, grazing & Settlements, agriculture, grazing & Settlements, agriculture, grazing \\
\hline Climate change & $\begin{array}{l}\text { Lower rainfall, increase in } \\
\text { droughts }\end{array}$ & $\begin{array}{l}\text { Increased annual mean tem- } \\
\text { perature and number of rainy } \\
\text { days. }\end{array}$ & $\begin{array}{l}\text { Predicted increase of } 3^{\circ} \mathrm{C} \text { and in- } \\
\text { crease in number of rainy days. }\end{array}$ \\
\hline \multicolumn{4}{|l|}{ The local drivers of change } \\
\hline Community & Unmitigated cultural changes & $\begin{array}{l}\text { Reconciliation between economic } \\
\text { groups. }\end{array}$ & $\begin{array}{l}\text { Traditional communities where } \\
50000 \text { depend on sustainable } \\
\text { wild coffee for their income. }\end{array}$ \\
\hline Tourism & $\begin{array}{l}\text { Income, service benefits, } \\
\text { environmental and cultural } \\
\text { degradation. }\end{array}$ & $\begin{array}{l}\text { Income and benefits from the } \\
\text { Kruger NP. }\end{array}$ & Starting to develop. \\
\hline Meaning of landscape & $\begin{array}{l}\text { Ancestral land and uses of } \\
\text { natural resources for cultural } \\
\text { practices. }\end{array}$ & $\begin{array}{l}\text { Traditional livestock rearing and } \\
\text { small-scale agriculture. }\end{array}$ & $\begin{array}{l}\text { Traditional forest landscape } \\
\text { deeply engrained in local } \\
\text { culture, economy and history. } \\
\text { People still live in traditional clay } \\
\text { huts. }\end{array}$ \\
\hline Conservation & $\begin{array}{l}\text { Maasai are culturally custodians } \\
\text { of nature. They did not know } \\
\text { about the international designa- } \\
\text { tions. }\end{array}$ & $\begin{array}{l}\text { The community is supportive } \\
\text { of the conservation efforts in } \\
\text { the BR. }\end{array}$ & $\begin{array}{l}\text { The BR was established to pro- } \\
\text { mote sustainable development } \\
\text { and stop the rapid deforesta- } \\
\text { tion of Ethiopia's Afromontane } \\
\text { forests. The community supports } \\
\text { the BR's initiatives. }\end{array}$ \\
\hline
\end{tabular}

importantly, the Tanzanian Wildlife Management Area which borders on SNBR has a comparatively new community-based conservation approach that may add value to the UNESCO BR approach (Kimario et al. 2020).

Our results suggest that three prominent drivers of change are insufficiently addressed within SNBR, namely population, culture, and climate. This is also the case in many other UNESCO sites worldwide (Job et al. 2017). First and most important in the short term, the increasing human and livestock populations are degrading NCA's natural areas and resources, because more space is used to build housing, and to produce food and grazing. As communities expand into natural habitats, more human-wildlife conflicts occur. Second, the Maasai's traditional sustainable culture is changing and becoming more resource-intensive. NCA management's neglect of social-cultural issues such as the in-migration of non-Maasai cultures, the commercialization of Maasai traditions and cultural goods, and the modernization of buildings, has contributed to this change. Third, cultural changes are accelerated by environmental stressors, such as climate change, which increase the incidence of waterborne diseases, and affect food security and access to water. According to Masao et al. (2015), a culture's perception of its place in the natural world, and its values and beliefs will change when the community's quality of life is threatened.

NCA's recognition for its outstanding universal value as a natural World Heritage site is most likely the reason management priorities are skewed towards environmental conservation. However, by neglecting social issues such as over-population and cultural changes within NCA, both its environmental quality and its attractiveness as a tourism destination may be affected negatively. Furthermore, conservation priorities are inequitable: communities' access to the few permanent water sources is restricted because these are situated within fragile ecosystems and wildlife habitats, yet mass tourism (which places high demands on limited water resources) is allowed in these areas. Such injustices and inconsistencies damage the relationship between the Maasai and NCA's management, and ultimately encourage non-respect for regulations.

The communities living in BRs that include Afromontane forests are often impoverished, naturedependent and over-populated (Mohammed 2020). Two BRs that have found ways to mitigate these challenges are the K2C BR (South Africa), a classified OECM, and Kafa BR (Ethiopia), a PA similar to SNBR (UNEP-IWCMC \& IUCN 2021).

The K2C BR $\left(26080 \mathrm{~km}^{2}\right.$; population 1.5 million) was established in 2001, to reconcile the impoverished, natural resource dependent population, who practise pastoralism and small-scale agriculture (and have also been displaced with the expansion of the Kruger NP), with the more affluent game ranching communities (K2C 2020; UNESCO 2019b), see Table 1. This BR is managed by private citizens, and village and government representatives. The benefits from K2C's projects must be shared amongst a large population, where 
$32 \%$ are under the age of 15 , and $41 \%$ of people aged 15-64 are unemployed (Municipalities 2021; Chidakel et al. 2020). The K2C has affected local communities' economic development only moderately through nature-based tourism, the creation of jobs in the Green Economy, and the support of local small businesses (Clifton 2018). BR communities are supportive of conservation initiatives, which is not always the case in villages outside the BR (Anthony 2007). Since K2C's establishment, the land cover has changed in the transition and buffer zones (the core has remained largely unchanged). The Afromontane forest in particular has been reduced in extent, as the increasing population cleared areas for settlements and agriculture (CoetzerHanack et al. 2016). The NP attracts more than one million tourists annually, which creates around 10400 tourism jobs and directly contributes US\$ 150 million to the local economy (Chidakel et al. 2020; SANParks 2020). Natural attractions and tourism are, however, threatened by climate change, as the mean annual temperature and number of days of rain have already increased (Wilgen et al. 2013).

Kafa BR (5 $406 \mathrm{~km}^{2}$; population 608227 ) was established in 2010 (UNESCO 2020) to improve sustainable development and stop the rapid deforestation of Ethiopia's Afromontane forests, see Table 1. Forty years ago, forest covered $40 \%$ of Ethiopia; now, only $3 \%$ of the original forests remain, most of which can be found in Kafa (Berghöfer et al. 2013). While Kafa does not have an NP that attracts tourists to the area, it does have a strict no-access core area that conserves the original indigenous coffee tree, Coffea arabica, and its almost 5000 variants. The region's deforestation is caused by the agricultural expansion (Mohammed 2020) of communities that still live in traditional huts and settlements scattered throughout the landscape. Livestock, which represents a family's wealth, is closely tied to the people's cultural heritage. The forest ecosystem provides the communities with food, firewood and grazing (NABU 2021), and is connected to their culture, economy and history. These communities are therefore a vital component in the BR's participatory forest management scheme, which allows local coffee farmers to collect and market wild coffee cherries. In return, they are responsible for the conservation of the forest. Reforestation is vital to combat climate change, as the temperature within Kafa is predicted to increase by $3^{\circ} \mathrm{C}$ accompanied by more days of rain (NABU 2013). Kafa's projects aim to find long-term socio-economic and environmental solutions through job creation, promoting carbon sequestration, and climate change mitigation (UNESCO 2017). Studies indicate that since the BR was established, communities feel more responsible for their forests and see the value of their protection. Today, some 50000 people depend on income from wild coffee, and through the BR's activities Kafa has gained international recognition as a producer of high-quality coffee (Berghöfer et al. 2013).
This comparison brings to light two issues affecting SNBR's efficacy at local level: the absence of community involvement, and of consideration of their socio-cultural heritage in management objectives. Environmental custodianship (including protection of the Afromontane forests) is part of the Maasai's culture (Merker 1904), which sets SNBR apart from the other two BRs. Of the three BRs, SNBR is the oldest, and landscape change takes place right next to the sensitive, restricted water-catchment area of its Afromontane forest zone (Kimario \& Job 2021). K2C BR and Kafa BR, established since 1995, have three explicit BR zones and focus on sustainable development. Landscape change mainly occurs in their transition and buffer zones, further away from the most vulnerable core (Coetzer-Hanack et al. 2016; Mohammed 2020). In SNBR, besides subsidizing cereals and building ponds and dams (which are a source of disease), little is done to find sustainable long-term solutions to climate change. While $\mathrm{K} 2 \mathrm{C}$ and Kafa try to address sustainable development and socio-cultural heritage issues in their landscapes, SNBR, in order to attain OECM goals, still needs to update its conservation approach to improve its impact on both the natural and the cultural landscapes.

\section{Conclusion}

SNBR undoubtedly has the potential to align with the OECM goals: it has a traditional, sustainable community that has lived in harmony with the landscapes' ecosystem dynamics for centuries; it also has the matchless natural beauty and rich biodiversity of the Ngorongoro Crater and the Serengeti. Conservation management in NCA should be expanded to include ecosystem services and socio-cultural heritage. Maasai culture is threatened, and young people should therefore be educated to appreciate and protect their heritage. Community members not interested in following the Maasai way of life could be encouraged to relocate to outside NCA: they could still access their ancestral lands, but not deplete its limited natural resources through agriculture and overgrazing. While such measures would lead to a loss of landscape meaning and cause some to reject conservation in the future, the further loss of the Maasai way of life and the natural SNBR landscape would reduce its tourism appeal and increase poverty. Projects that provide long-term solutions to mitigate the impact of climate change should also be implemented. In support of these measures, SNBR's management could demarcate three clear zones following UNESCO's global BR aims, where community and tourist industry policies could be adapted for sustainable development, which should mitigate the negative impacts on natural processes. A sustainable compromise between strict conservation measures and the community's needs within SNBR might serve to create a basis for action. 


\section{Acknowledgements}

We would like to thank the Maasai people and the park administration for their willingness to share information and their experiences.

\section{References}

Abiem, I., G. Arellano, D. Kenfack \& H. Chapman 2020. Afromontane Forest Diversity and the Role of Grassland-Forest Transition in Tree Species Distribution. Diversity 30(12): 1-19.

Anthony, B. 2007. The dual nature of parks: Attitudes of neighbouring communities towards Kruger National Park, South Africa. Environmental Conservation 34(3): 236-245.

Becken, S. \& H. Job 2014. Protected Areas in an era of global-local change. Journal of Sustainable Tourism 22(4): 507-527.

Bell, A., N. Bolomey \& C. Ivins 2013. Nominating UNESCO World Biosphere Reserves in Tanzania. Dar es Salaam.

Berghöfer, A., C. Stadler \& G. Langdale 2013. Sustaining Life: The Cloud Forests of Kafa'. Marketing Concept for the Kafa Biosphere Reserve, Ethiopia. Berlin

Botha, N. 2020. Agriculture vs. conservation: how Grootvadersbosch Conservancy finds the common ground. South African Geographical Journal 102(3): 372388.

Carius, F. \& H. Job 2019. Community involvement and tourism revenue sharing as contributing factors to the UN Sustainable Development Goals in JozaniChwaka Bay National Park and Biosphere Reserve, Zanzibar. Journal of Sustainable Tourism 27(6): 826-846.

Chidakel, A., C. Eb \& B. Child 2020. The comparative financial and economic performance of PAs in the Greater Kruger National Park, South Africa: functional diversity and resilience in the socio-economics of a landscape-scale reserve network. Journal of Sustainable Tourism 28(8): 1100-1119.

Clifton, K.L. 2018. The impact of constituency building on development and conservation sentiment in the Kruger to Canyons Biosphere. Bryan.

Coetzer-Hanack, K., E. Witkowski \& B. Barend 2016. Thresholds of change in a multi-use conservation landscape of South Africa: historical land-cover, future transformation and consequences for environmental decision-making. Environmental Conservation 1: $1-10$.

Grimshaw, J. 2001. What do we really know about the Afromontane Archipelago? Systematics and Geography of Plants 71(2): 949-957.

IUCN 2019. Guidelines for recognising and reporting "Other Effective Area-based Conservation Measures". Gland.

IUCN-WCPA 2019. Recognising and reporting other effective area-based conservation measures. Gland.

Job, H., S. Becken \& B. Lane 2017. Protected Areas in a neoliberal world and the role of tourism in supporting conservation and sustainable develop- ment: an assessment of strategic planning, zoning, impact monitoring, and tourism management at natural World Heritage Sites. Journal of Sustainable Tourism 25 (12): 1697-1718.

Job, H., M. Engelbauer \& B. Engels 2019. Das Portfolio deutscher Biosphärenreservate im Lichte der Sustainable Development Goals. Raumforschung und Raumordnung 77(1): 57-79.

Job, H. \& L. Schmid 2011. Serengeti Shall Not Die!: 50 Years of integrated national park management in Tanzania. Natur und Landschaft 86(2): 52-58.

K2C (Kruger to Canyons) 2020. Kruger to Canyons. Available at: https://kruger2canyons.org (accessed: 03/09/2020).

Kimario, F. 2018. Synergies of natural and cultural capital in the Ngorongoro Conservation Area, Tanzania. Unpublished Master Thesis, Albert-Ludwigs-Universität Freiburg.

Kimario, F., N. Botha, A. Kisingo \& H. Job 2020. Theory and practice of conservancies: evidence from wildlife management areas in Tanzania. Erdkunde 74(2): 117-141. Bonn.

Kimario, F. \& H. Job 2021. Synergies of natural and cultural capital in the Ngorongoro Conservation Area, Tanzania. $13^{\text {th }}$ TAWIRI Scientific Conference. Arusha.

Larsen, F., J. Grant, C. Hopcraft, N. Hanley, J.R. Hongoa, S. Hynes, M. Loibooki, G. Mafuru, K. Needham, F. Shirima \& T.A. Morrison 2020. Wildebeest migration drives tourism demand in the Serengeti. Biological Conservation 248 (108688).

Mbise, A.S. 1996. Pre-primary education versus primary education. Education and Development 16: 39-51.

Masao, C.A., M. Revocatus \& S. Hussein 2015. Will Ngorongoro Conservation Area remain a world heritage site amidst increasing human footprint? International Journal of Biodiversity and Conservation 7: 394-407.

Merker, M. 1904. Die Masai: Etnographische Monographie eines ostafrikanischen Semitenvolkes. Berlin.

Mohammed, A.Y. 2020. A review on Kafa Biosphere Reserve: roles in meeting sustainable development of Ethiopia. Journal of Medicinal Plants Studies 8(4): 222-226.

Municipalities 2021. Municipalities of South Africa. Available at: https://municipalities.co.za (accessed: 03/09/2020)

NABU (Nature and Biodiversity Conservation Union) 2013. Manual for youth-to-youth training. Berlin.

NABU (Nature and Biodiversity Conservation Union) 2021. The People of Kafa: Local communities depend on the forest. Available at: https://en.nabu.de/topics/ regional-development/coffee-novation/people (accessed: 03/05/2021)

NCAA (Ngorongoro Conservation Area Authority) 2020. Tourism Statistics 2019 Report. Arusha.

Newmark, W. 2002. Conserving Biodiversity in East African Forests: A Study of the Eastern Arc Mountains. Salt Lake City.

Price, M.F., G. Gratzer, L.A. Duguma, T. Kohler, D. Maselli \& R. Romeo (eds.) 2011. Mountain Forests 
in a Changing World: Realizing Values, addressing challenges. Rome.

SANParks (South African National Parks) 2020. Annual report 2019/20. Pretoria.

TEEB (The Economics of Ecosystems and Biodiversity) 2021. The evaluation framework. Available at: http://teebweb.org (accessed: 01/01/2021).

Udvardy, M.D.F. 1975. A classification of the biogeographical provinces of the world. IUCN Occasional Paper no. 18. Morges.

UNEP-WCMC \& IUCN 2021. Protected Planet: The world database on protected areas. Available at: www. protectedplanet.net (accessed: 24/05/2021).

UNESCO 2017. UNESCO Kafa Biosphere Reserve: Saving the Last Wild Coffee Forests. Available at: http://www.unesco.org/new/en/natural-sciences/ environment/ecological-sciences/infocus-ecologicalsciences/unesco-kafa-biosphere-reserve-saving-thelast-wild-coffee-forests/ (accessed: 01/01/2021).

UNESCO 2019a. Serengeti-Ngorongoro Biosphere Reserve, Tanzania. Available at: https://en.unesco.org/ biosphere/africa/serengeti-ngorongoro (accessed: 29/07/2020)

UNESCO 2019b. The UNESCO MAB programme in South Africa. Pretoria.

UNESCO 2020. World Network of Biosphere Reserves. Available at: https://en.unesco.org/biosphere/wnbr (accessed: 01/01/2021)

URT (United Republic of Tanzania) 2017. Population and Livestock Census for Ngorongoro Division. Dar es Salaam.

Wilgen, N.J., V. Goodall \& M.A. McGeoch 2013. Impacts and trends in climate change and other drivers in South African national parks. Available at: https://www. sanparks.org/assets/docs/parks_kruger (accessed: $01 / 01 / 2021)$

\section{Authors}

\section{Nina Botha}

has a Master's degree from Stellenbosch University, South Africa. Since April 2021, she has been continuing her studies with a PhD, at Julius-Maximilians-University of Würzburg, relating to climate change adaption and mitigation strategies in biosphere reserves of Southern Africa. Stellenbosch University, Department of Geography and Environmental Studies, Private Bag X1, Matieland, 7602 Stellenbosch, South Africa. E-mail: 25ninatjie@gmail.com

\section{Hubert Job}

holds a degree in geography. He is an elected member of the German Academy for Spatial Research and Planning, and an appointed member of the German National Committee for the UNESCO Man and the Biosphere Programme. Julius-Maximilians-University of Würzburg, Institute for Geography and Geology, Chair of Geography and Regional Science, Am Hubland, 97074 Würzburg, Germany. E-mail: hubert. job@uni-wuerzburg.de

\section{Fidelcastor Kimario}

holds a Master's degree from the University of Freiburg, Germany. He works for the Tanzanian Ministry of Natural Resources and Tourism as a Community-Based Conservation Officer. In October 2021, he will be enrolling for $\mathrm{PhD}$ studies at the Julius-Maximilians-University of Würzburg, to work on biodiversity conservation and community livelihoods in the rural periphery of Tanzania. Ministry of Natural Resources and Tourism, Government City - Mtumba, Prime Minister's Street, P.O. Box 1351, 40472 Dodoma, Tanzania. E-mail: fidelkimario@yahoo.com 